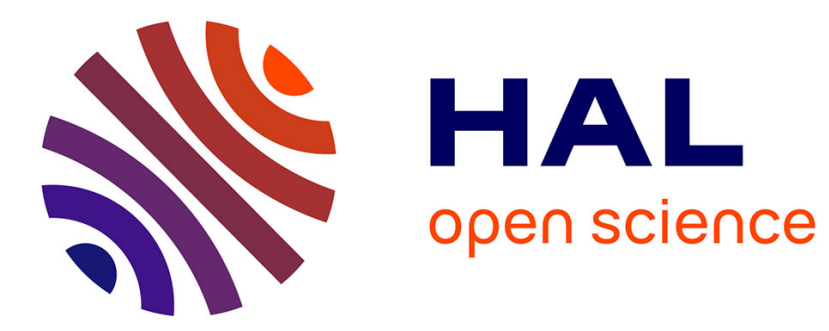

\title{
Internet access: where law, economy, culture and technology meet
}

\author{
Sulan Wong, Eitan Altman, Julio Rojas-Mora
}

\section{To cite this version:}

Sulan Wong, Eitan Altman, Julio Rojas-Mora. Internet access: where law, economy, culture and technology meet. 2010. inria-00523211

\section{HAL Id: inria-00523211 \\ https://hal.inria.fr/inria-00523211}

Preprint submitted on 4 Oct 2010

HAL is a multi-disciplinary open access archive for the deposit and dissemination of scientific research documents, whether they are published or not. The documents may come from teaching and research institutions in France or abroad, or from public or private research centers.
L'archive ouverte pluridisciplinaire HAL, est destinée au dépôt et à la diffusion de documents scientifiques de niveau recherche, publiés ou non, émanant des établissements d'enseignement et de recherche français ou étrangers, des laboratoires publics ou privés. 
INSTITUT NATIONAL DE RECHERCHE EN INFORMATIQUE ET EN AUTOMATIQUE

\title{
Internet access: where law, economy, culture and technology meet
}

\author{
Sulan Wong — Eitan Altman — Julio Rojas-Mora
}

\section{$\mathbf{N}^{\circ} \mathbf{7 4 0 5}$}

Sep 2010

Thème COM 



\title{
Internet access: where law, economy, culture and technology meet
}

\author{
Sulan Wong* , Eitan Altman ${ }^{\dagger}$, Julio Rojas-Mora ${ }^{\ddagger}$ \\ Thème COM - Systèmes communicants \\ Équipe-Projet Maestro
}

Rapport de recherche $\mathrm{n}^{\circ} 7405-$ Sep $2010-23$ pages

\begin{abstract}
Internet growth has allowed unprecedented widespread access to cultural creation including music and films, to knowledge, and to a wide range of consumer information. At the same time, it has become a huge source of business opportunities. Along with great benefits that this access to the Internet provides, the open and free access to the Internet has encountered large opposition based on political, economical and ethical reasons. An ongoing battle over the control on Internet access has been escalating on all these fronts. In this paper we describe first some of the ideological roots of free access to the Internet along with its main opponents. We then focus on the problem of "Internet piracy" and analyze the efficiency of efforts to reduce the availability of copyrighted creations that are available for non-authorized free download.
\end{abstract}

Key-words: Internet access, fundamental rights, copyrights, public goods, commons

\footnotetext{
* Faculty of Law, Campus of Elviña, University of A Coruña, 15071 A Coruña, Spain. Email: swong@udc.es

${ }^{\dagger}$ Project Maestro, INRIA Sophia-Antipolis, France. Email: eitan.altman@sophia.inria.fr

* Faculty of Economic and Business Sciences, University of Barcelona, o8034 Barcelona, Spain. Email: jrojasmo7@alumnes.ub.edu
} 


\section{Accès Internet: où le droit, l'économie, la culture et la technologie se rencontrent}

Résumé : La croissance d'Internet a permis un accès généralisé et sans précédent à la création culturelle, y compris à la musique et à des films, ainsi que à la connaissance, et à un large éventail d'information sur le consommateur. Au même temps, l'internet est devenue une énorme source d’opportunités pour les affaires. Avec les grands avantages que cet accès à l'Internet offre, l'accès ouvert et libre à l'Internet a rencontré une opposition importante qui repose sur des raisons politiques, économiques et éthiques. Il y a actuellement une bataille sur le contrôle de laccès à Internet qui a des répercutions sur tous ces fronts. Dans cet article, nous décrivons d'abord quelques des racines idéologiques de l'accès libre à l'Internet ainsi que ses principaux opposants. Nous avons ensuite mis l'accent sur le problème de "piratage sur Internet" et nous nous employons à analyser l'efficacité des efforts visant à réduire la disponibilité des créations protégées qui sont disponibles pour téléchargement libre non-autorisée.

Mots-clés : Accès à Internet, droits fondamentaux, droits d'auteur, biens publics, commons 


\section{Introduction}

As technology allows very high speed access to the Internet for hundreds of millions of people around the world, the pervasive nature of the Internet draws growing opposition. Those who try to restrict, to control or to filter access to the Internet include a wide variety of actors motivated by quite different reasons ranging from security to political and ideological ones, as well as economic interests

This work has been triggered by an ongoing legislation battle in France between two opposed approaches for dealing with copyright infringements over the Internet and with non-authorized download of copyrighted content. One approach proposes to ban such downloads and to establish a heavy control on downloads, while the other proposes to establish a general tax on internauts that wish to pursue downloading. The revenues of the tax would be redistributed among the copyright owners.

The HADOPI law can be associated with two basic types of restrictions of the access to the Internet. First, there is a legal limit, that in absence of this law would not be clearly defined, over the content that can be accessed and downloaded through the Internet. Second, there is also the suspension of the Internet access service that the law imposes as part of the sanctions against unauthorized file sharing by an Internet subscriber. Other countries have implemented different types of access restrictions like, for example, blocking access to $\mathrm{P}_{2} \mathrm{P}$ sites, throttling the traffic of $\mathrm{P}_{2} \mathrm{P}$ users and blocking the use of $\mathrm{P}_{2} \mathrm{P}$ file sharing protocols.

The French constitutional Court has rejected some aspects of the original HADOPI Act citing the Declaration of the Rights of Man and the Citizen 1789, which dates back to more than two centuries before the Internet. This link may have come as a surprise to many of those involved in developing and deploying the Internet, who may not be aware of what the Internet represents for society beyond its technological revolutionary features and characteristics.

The first part of this paper examines the ideological and legal role of Internet access. We begin by recalling in the next section several historical human rights declarations that had later an impact on legislation concerning Internet access. We then present, in the following section, an overview of legislation and rulings concerning Internet access which refer to these declarations. In the second part of the paper we present a socio-economic vision of the role of the Internet. In Section 4, we examine its identification as a "public good", and address the classical issues related to public goods: that of free riders and of provisioning. We then present an overview of work on the role of the Internet access as a "commons" and address, in particular, the role of wireless access to the Internet. We end the paper with a section that proposes some recommendations on the future of the Internet. 


\section{Human Right Declarations}

There are three important documents in the history of human rights: the Virginia Declaration of Rights of $1776^{1}$, the United States Declaration of Independence of 1776 , and the Declaration of the Rights of Man and of the Citizen of $1789^{2}$. Whether these texts originated independently, or, on the other hand, were mutually influenced by each other, is a doctrinal discussion in the field of law [35]. What is indisputable is that the ideas of the rational natural school ${ }^{3}$ are present in these declarations:

"That all men are by nature equally free and independent and have certain inherent rights, of which, when they enter into a state of society, they cannot, by any compact, deprive or divest their posterity; namely, the enjoyment of life and liberty, with the means of acquiring and possessing property, and pursuing and obtaining happiness and safety" is found in the Virginia Declaration of Rights.

"That all men are created equal; that they are endowed by their Creator with certain unalienable rights; that among these are life, liberty, and the pursuit of happiness" states the United States Declaration of Independence.

"Men are born and remain free and equal in rights" said thirteen years later the Declaration of the Rights of Man and of the Citizen.

Since then, life, liberty and equality were recognized in successive western constitutional texts as fundamental rights of every human being. Both, French and American constitutional texts consecrate the principles considered in the declarations, albeit in different ways ${ }^{4}$. Worldwide recognition of these principles was achieved with the first article of the Universal Declaration of Human Rights of 1948:

"All human beings are born free and equal in dignity and rights."

\section{Recognition of Internet access as a fundamental right}

Freedom has many manifestations, e.g., freedom of expression and opinion, freedom of press, freedom of thought, conscience and religion, freedom of communication. All these forms in which freedom is manifested, in turn require guarantees to assure its exercise in all areas, regardless of frontiers and by any means of expression ${ }^{5}$.

\footnotetext{
${ }^{1}$ The Virginia Declaration of Rights (1776) was the model used for the Bill of Rights by other states of the American Union.

${ }^{2}$ The Declaration of the Rights of Man and of the Citizen 1789 is considered the first form of recognition of individual rights and liberties in a legal instrument of any European country [46, p. 121].

${ }^{3}$ Grocio, Hobbes, Spinoza, Locke, Pufendorf, Leibniz, Tomasio, Rousseau and Kant are considered the most representative philosophers of the XVII, XVIII and XIX centuries, who developed the natural law theory based on reason [7].

${ }^{4}$ The French throughout in the preamble, while the Americans, on the other hand, through amendments.

${ }^{5}$ Article 19 of the Universal Declaration of Human Rights reminds all States that freedom of speech "includes freedom to hold opinions without interference and to seek, receive and impart information and
} 
Several explicit links between human rights and Internet access have appeared in the last years. The European Parliament [22] believes that the Internet is a universal space that now allows the pursuit of all these manifestations of freedom as enshrined in the Universal Declaration of Human Rights, and the International Covenant on the Rights Civil and Political Rights, becoming the most versatile tool for the exercise of freedom of expression globally. To that extent, the Internet should not be subjected to "interference by public authority" ${ }^{6}$, or limitation of access or control of content. The Spanish Senate recognized that all people have a fundamental right to access the Internet, without any discrimination. As freedom is an inherent condition to the Internet, it admitted the principle that no power can restrict this freedom and that its limits can only come from the Declaration of Human Rights ${ }^{7}$.

Internet access in the European Union is seen as a "universal service", i.e., one that must be provided by Member States "at the quality specified to all end-users in their territory, independently of geographical location, and, in the light of specific national conditions, at an affordable price" [26, Art. 3]. Fixed location services have to be capable of "data rates that are sufficient to permit functional Internet access, taking into account prevailing technologies used by the majority of subscribers and technological feasibility" ([26, Art. 4] replaced by [28, Art. 1.3]). Expanding on this same line, the Ministry of Transport and Communication of Finland has passed a Decree in October 2009 on the caracteristics that the access to Internet, as a universal service, should have [40]. In it, the Ministry demands from providers that fixed broadband connections should be ensured with an average rate of at least one Mbps and that by 2015 a $100 \mathrm{Mbps}$ backbone is within $2 \mathrm{Km}$ of every permanent connection.

Internet's administrative intervention in the European Union was one of the most controversial issues in discussions on the reform of the so called Telecom ${ }^{8}$ package. It was expected that the European Parliament would promote legislative measures aimed at strengthening Internet end-user's fundamental rights and freedoms, keeping Amendment 138 as proposed:

"that no restriction may be imposed on the fundamental rights and freedoms of end-users, without a prior ruling by the judicial authorities, notably in accordance with Article 11 of the Charter of Fundamental Rights of the European Union on freedom of expression and information, save when public security is threatened where the ruling may be subsequent."

ideas through any media and regardless of frontiers." In the same line, Article 19.2 of the International Covenant on Civil and Political Rights declares that "[e]veryone shall have the right to freedom of expression; this right shall include freedom to seek, receive and impart information and ideas of all kinds, regardless of frontiers, either orally, in writing or in print, in the form of art, or through any other media of his choice."

${ }^{6}$ See Art. 10.1 [29]

${ }^{7}$ See Spanish Senate diary of sessions of 9 December, 1999 at http://www.senado.es/ comredinf/ds/index.html

${ }^{8}$ The set of directives governing telecommunications in the European Union, whose recent amendments have been incorporated in the Directive 2009/136/CE. 
This proposition, supported several times by the European Parliament [27], [21], [23], [22], was amended at the eleventh hour of the discussions of the Telecom package, as keeping it without change went "beyond the competence of the Community as laid down in Article 95 of the EC Treaty."

This new position, which was included in the Directive 2009/136/CE [28, Art. 1.3], opens the door to the intervention of Internet communications through administrative procedures, although it calls for respect of fundamental rights and freedoms, as well as due process guarantees:

"Member States are encouraged to draw up, for themselves and in the interests of the Community, their own tables illustrating, as far as possible, national measures regarding end-users' access to, or use of, services and applications through electronic communications networks, shall respect the fundamental rights and freedoms of natural persons, including in relation to privacy and due process, as defined in Article 6 of the European Convention for the Protection of Human Rights and Fundamental Freedoms."

The first amendment of the United States Constitution prohibits Congress to pass laws that abridge the freedom of speech or press. Nonetheless, in 1996 the USA Congress approved the Communications Decency Act (CDA) to protect minors from "indecent" and "patently offensive" communications that "an international network of interconnected computers that enables millions of people to communicate with one another in 'cyberspace' and to access vast amounts of information from around the world", allows [54]. This form of censorship of the freedom of speech was alerted by the American Civil Rights Union (ACLU) who filed a civil action against the CDA. The decision of the special three-judge panel in ACLU, et al. $v$. Reno [6o] was favorable to freedom of speech, as it stated that:

"the Internet may fairly be regarded as a never-ending worldwide conversation. Government may not, through the CDA, interrupt that conversation. As the most participatory form of mass speech yet developed, the Internet deserves the highest protection from governmental intrusion."

Furthermore, this Court said that parents:

"can install blocking software on their home computers, or they can subscribe to commercial online services that provide parental controls. It is quite clear that powerful market forces are at work to expand parental options to deal with these legitimate concerns. More fundamentally, parents can supervise their children's use of the Internet or deny their children the opportunity to participate in the medium until they reach an appropriate age."

\footnotetext{
${ }^{9}$ See the document A7-0070/2009 of European Parlament available in http://www .europarl.europa.eu
} 
It is interesting what judge Dalzell explains before concluding that the CDA was unconstitutional:

"Just as the strength of the Internet is chaos, so the strength of our liberty depends upon the chaos and cacophony of the unfettered speech the First Amendment protects. The Internet and other online computer networks merit the highest protection from governmental intrusion."

Thus, the Supreme Court upheld the lower court judgment and the CDA was deemed unconstitutional:

"The interest in encouraging freedom of expression in a democratic society outweighs any theoretical but unproven benefit of censorship" [54].

The CDA was followed by the Child Online Protection Act (COPA), which was called "Congress Decency Act II" by its critics, a scathing reference to their common goal. The Act sought the "restriction of access by minors to materials commercially distributed by means of world wide web that are harmful to minors." The term "material that is harmful to minors", whose commercial distribution entailed criminal sanctions, means any communication, picture, image, graphic image file, article, recording, writing, or other matter of any kind that is obscene or that:

"(a) the average person, applying contemporary community standards, would find, taking the material as a whole and with respect to minors, is designed to appeal to, or is designed to pander to, the prurient interest;

(b) depicts, describes, or represents, in a manner patently offensive with respect to minors, an actual or simulated sexual act or sexual contact, an actual or simulated normal or perverted sexual act, or a lewd exhibition of the genitals or post-pubescent female breast; and

(c) taken as a whole, lacks serious literary, artistic, political, or scientific value for minors." [55, Apendix A]

The COPA, like the CDA, reached the Supreme Court [55] who this time did not rule on its constitutionality, limiting its decision to:

"hold only that COPA's reliance on community standards to identify 'material that is harmful to minors' does not by itself render the statute substantially overbroad for purposes of the First Amendment. We do not express any view as to whether COPA suffers from substantial overbreadth for other reasons, whether the statute is unconstitutionally vague, or whether the District Court correctly concluded that the statute likely will not survive strict scrutiny analysis once adjudication of the case is completed below. While respondents urge us to resolve these questions at this time, prudence dictates allowing the Court of Appeals to first examine these difficult issues." 
The case was forwarded to the Court of Appeals [59] who stated that the COPA was unconstitutional:

"to avoid liability under COPA, affected Web publishers would either need to severely censor their publications or implement an age or credit card verification system whereby any material that might be deemed harmful by the most puritan of communities in any state is shielded behind such a verification system. Shielding such vast amounts of material behind verification systems would prevent access to protected material by any adult seventeen or over without the necessary age verification credentials. Moreover, it would completely bar access to those materials to all minors under seventeen - even if the material would not otherwise have been deemed 'harmful' to them in their respective geographic communities."

In France, things have not been very different. With the HADOPI Act, which by means of an administrative procedure orders the disconnection of $\mathrm{P}_{2} \mathrm{P}$ users that share copyrighted cultural contents, the Constitutional Council went back to the Declaration of the Rights of Man and of the Citizen to conclude that the freedom of speech could not be trusted to a new nonjudicial authority in order to protect holders of copyrights and neighbouring rights, as the "free communication of ideas and opinions is one of the most precious of the rights of man" [14]. The Council recognizes that Internet is a powerful tool in the exercise of the freedom of speech and this is why only a court of law -as guardian of freedom- can restrict access to it. Therefore, Internet access acquires the level of a fundamental right.

The response of the Executive against the Constitutional Council's decision was almost immediate. Less than fifteen days were enough to present a criminal bill (HADOPI II Act) to the Senate [39], in order to complete the mechanism of "graduated response" of the HADOPI Act. Copyrighted content file-sharing becomes a form of piracy, a criminal offense that can only be declared by a court of law, theoretically solving the questions posed by the Council. Hence, after the warnings have been submitted to the infringer, the case is brought to a criminal court that might sentence him with the suspension of Internet access for up to a year and a ban on signing a new contract.

In summary, we witness a wide scale recognition of the Internet access as a basic human right. This view will certainly have a great impact on the Internet of the future. However, there is an ongoing struggle on the extent of Internet access and of measures to control it that may have a huge impact on tomorrow's Internet, a struggle between a confrontational approach, aiming at banning physical access to copyrighted content on the Internet ${ }^{10}$ and on the other, an approach aiming at taxing such access.

\footnotetext{
${ }^{10}$ The secretive way with which the USA, EU, Mexico, Japan, Canada, South Korea, Australia and other countries have been negotiating an agreement to implement a worldwide HADOPI-like model is a clear example of a strategy aiming at controlling the Internet. For more information see Michael Geist's report in http: //www .mi chaelgeist.ca/, and La Quadratura du Net coverage in
} 


\section{Cultural resources in Internet as a public good}

\subsection{Public goods}

In the economic literature [50] a public good is defined as a good that is non-rivalrous and non-excludable. Non-rivalrous because the consumption of the good by one user will not leave less of the resource for the remaining users. Non-excludable because the consumption of the good doesn't exclude other users from simultaneously consuming it. In this sense, the good is public not because it is produced by a public entity, but because its consumption is publicly available.

Cultural contents share these characteristics, meaning they can be seen as public goods. But the Legislator has created, with copyrights, artificial means to limit access to them. The reproduction of cultural contents has been the main monopoly on which the cultural contents production industry (CPI) has based its revenue. If everybody could copy cultural contents without paying compensations to the CPI, the industry and the authors would be put in an impasse.

\subsection{The free rider problem}

Olson [42] thought that people would become active in promoting a common interest only if the group is small or they are forced to do it. Otherwise, they would only act according to their individual interests, even if that impairs the common goal. This selfish individual, the free rider, will not feel obliged to contribute voluntarily to the provision of the common good once it has been produced, as he cannot be excluded from reaping the benefits. At the heart of every collective action model, Ostrom [43] says, lies the problem of the free rider.

In the file sharing context, $\mathrm{P}_{2} \mathrm{P}$ users are seen as free riders by the $\mathrm{CPI}$, as they can acquire cultural contents they like without paying for them. Thus, economic compensation can be equated to some sort of provisioning of the public good, as authors, performers and the CPI contribute with cultural contents, but users of $\mathrm{P}_{2} \mathrm{P}$ networks have no other way to do it. Interestingly, among engineers and researchers who develop $\mathrm{P}_{2} \mathrm{P}$ protocols, a free rider has the opposite meaning: it is someone who does not share with others the files he has.

\subsection{Provision of the public good}

The reproduction of copyrighted cultural contents "in any manner or form" [66, Art. 9.1] is an exclusive right granted to authors, performers and producers of cultural contents, as well as broadcasting organizations $[66,70,68,67,25]$. This means that to reproduce a work protected by copyright laws, the authorization from rightholders

http: //www . laquadrature.net/acta. The European Parliament has also expressed in a resolution [24] "its concern over the lack of a transparent process in the conduct of the ACTA negotiations, a state of affairs at odds with the letter and spirit of the TFEU; is deeply concerned that no legal base was established before the start of the ACTA negotiations and that parliamentary approval for the negotiating mandate was not sought". 
should be obtained. However, this right may have some exceptions in "special cases", provided that the reproduction does not conflict with the "normal exploitation" of the work or that the exemption causes "unreasonable prejudice" to the copyright holders interests [66, Art. 9.2], [70, Art. 13], [68, Art. 16.2]. Within the framework of the European Union and with the aim of harmonizing the rules on copyright in the member States, a common scheme of legal limitations or exceptions regarding the reproduction of cultural contents is incorporated in the directive $29 / 2001 / \mathrm{CE}$, allowing the development and smooth functioning of the cultural industries. Thus, we find in the European economic context the enforceability of a "fair compensation"11 to those, who for private use, reproduce copyrighted works ${ }^{12}$.

Two schemes of compensation can be seen in different legislations throughout the world; we describe these in the two following subsections. We also describe YouTube's initiative as a way for the private initiative to provide for the public good.

\subsubsection{The private copying levy on recordable media, reproduction equipment and Internet access}

The private copy levy is a compensation mechanism that is established on analog and digital devices that allow unauthorized copying of cultural contents. This tax is based on the idea of uncontrolled future events that the use of such equipment may trigger in the economic exploitation of cultural works ${ }^{13}$.

The levy may depend on the ability to copy that the device allows [49]. The distribution of revenue collected may depend on a law or on a contract subject to the supervision of a public authority ${ }^{14}$

The indiscriminate way by which the levy is usually applied, has been the key rebuttal argument by consumer associations [3], [57], since in many cases those who acquire the cultural content, do not intend to copy or, actually, make copies of it, and the consumer who buys blank media does it not necessarily with the intent of copying copyrighted works.

The possibility of applying this levy on the Internet connections is a solution to the file sharing issue that has not been entirely abandoned in the public debate. We believe that the European Legislator [25, Recital 35] wanted to avoid that consumers incur a double payment of the levy, and hence it is established only as an exception to the exclusive right of reproduction that the rightholders have on their works ${ }^{15}$.

\footnotetext{
${ }^{11}$ For more information see [20]

${ }^{12}$ On the other hand, United Kingdom, Cyprus, Ireland, Luxembourg and Malta do not provide compensation for private copying in their legislations.

${ }^{13}$ The damage claimed by the CPI is based on the idea that every "single" or CD not sold is due to the acquisition of a copy. However, it is not clear that anyone who is not allowed to get a copy of a cultural content is going to replace it by buying the original.

${ }^{14}$ To know more on the distribution mechanism see [19, pp. 3-5].

${ }^{15}$ The ADSL connection is merely a connection, not a reproduction equipment, thus it cannot lead to any private copy levy [48].
} 
The establishment of a levy on the connection may also lead Internet users to assume that they have acquired a legitimate right of reproduction, rather than an obligation to compensate, on the works they have downloaded through the Internet.

\subsubsection{Blanket license}

An alternative legislative approach to restricting access has been to impose taxes on Internet access. Who would pay the tax? Several proposals have been considered: (i) all subscribers to the Internet access, (ii) all subscribers to high bandwidth access, (iii) all subscribers except those who declare they will not download unauthorized files.

In France, in the National Assembly debates on the DADVSI ${ }^{16}$ Act, an amendment to the Intellectual Property Code that promoted the creation of an Optional Blanket License (OBL) to legalize noncommercial filesharing of cultural contents protected by copyright and compensate their rightholders, was proposed.

This $\mathrm{OBL}^{17}$ was essentially an authorization granted by the authors to Internet users for unlimited access to their work, in exchange for a flat monthly payment ${ }^{18}$ made as compensation. This compensation would have been collected by the ISPs and collectively managed.

The proposal did not find support among the CPI and was eventually rejected by the French parliament arguing that it benefited neither the creators nor the consumers, because:

1. The ISPs would have been forced to implement surveillance measures on the network ${ }^{19}$.

2. The license would have increased the subscription price of Internet access ${ }^{20}$.

3. It did not respect the chronology of the media ${ }^{21}$. By contrast, in European countries like UK, Spain, Denmark, Italy, Serbia and Lithuania, there are no laws that guarantee a chronology [36].

\footnotetext{
${ }^{16}$ The Loi sur le Droit d'Auteur et les Droits Voisins dans la Société de l'Information (Loi Nro. 2006-961 du 1er Août), was drafted to transpose EU directive 2001/29/CE into French law.

${ }^{17}$ Supported by more than 14 , ooo authors, performers, producers, designers, photographers and consumers of L'Alliance "Public-Artistes". See http: //www . lalliance . org/pages/1_1.html.

${ }^{18}$ Between 5 to 7 Euros.

${ }^{19}$ The OBL posed a "tragedy of the commons" [33], as the lack of control mechanisms gives no incentive to pay the license. See Subsection 5.1.

${ }^{20}$ If no surveillance measures are implemented, the license should be compulsory, with the increased price of subscription service a logical consequence.

${ }^{21}$ The chronology of the media is a protectionist measure designed to ensure the economic development of the domestic film industry versus the foreign one. The aim of the measure is to establish a schedule -after the premiere in cinemas- for dissemination of film in other media. Mandatory minimum periods have to be completed before moving films from cinemas to home video (DVD, Blu-ray disc), and from it to television broadcasts. In France, an agreement has been recently signed to adjust the chronology of the media (see Arrêté du 9 juillet 2009 pris en application de l'article 30-7 du code de l'industrie cinématographique, NOR: MCCKo916018A).
} 
4. There was no viable proposition for the distribution of revenue collected ${ }^{22}$.

However, a group of parliament members were reluctant to abandon the idea that, in France, the internauts could opt for a blanket license: nine identical proposals asking for its implementation have been discussed in the parliamentary debate ${ }^{23}$ of the HADOPI II Act, and again, they have been rejected by the majority using, basically, the same arguments used to reject the OBL proposed in the DADVSI Act 24.

A similar proposal has been raised by the Electronic Frontier Foundation (EFF) as a legitimating mechanism of a socially accepted Internet behavior [63]. The Songwriters Association of Canada (SAC) promotes a "proposal for the monetization of the file sharing of music from the songwriter and recording artists of Canada", i.e., a blanket license for file sharing. For this license, the rightholders ask for the reform of the Copyright Act, in which a new reproduction right ${ }^{25}$, to obtain compensation for the reproduction of their works through file sharing, will be recognized. Although a file-sharing license is proposed on an optional basis, the fee will only be exempted if the Internet user agrees not to perform file-sharing and, if caught, he agrees to pay a predetermined compensation in damages.

These proposals have several common elements:

1. Existence of a collecting society for the distribution of the revenue.

2. ISPs will act as fee collecting entities.

3. Internet service subscribers will make a monthly payment of the license fee.

4. Voluntary participation of creators, rightholders and Internet users.

5. Legalization of the exchange of cultural contents on the Internet.

Notwithstanding, there are voices like that of Birmingham City University Andrew Dubber, who opposes this kind of licensing scheme arguing that it will only solve the cash flow of the major recording labels and that ISPs should not be a police force and revenue collecting agency of the $\mathrm{CPI}^{26}$. With this in mind, Harvard professor William Fisher has launched in Hong Kong a commercial application called Noank ${ }^{27}$, which is based on his proposal for a global license as an alternative compensation mechanism [30]. In it, the control, collection and pricing strategies are managed centrally, using a client that can search for and download the required contents. Right

\footnotetext{
${ }^{22}$ The fact that the blanket license involved a distribution of income based on a representative sample of works downloaded through the $\mathrm{P}_{2} \mathrm{P}$ networks with no correlation with the market reality, was questioned.

${ }^{23}$ See http://www. assemblee-nationale.fr/13/dossiers/protection_penale_ proplitt.asp

${ }^{24}$ In http: //www . assemblee-nationale.fr/13/cri/2008-2009-extra/20091027 . asp.

${ }^{25}$ It is our opinion that more than a new right of reproduction, what they ask for is the specification of a particular way of reproduction of works subject to copyright rules.

${ }^{26}$ See http: / /www . musicthinktank.com/blog/the-blanket-license-debate.html

${ }^{27}$ See http: / /www. noankmedia.com/howi tworks.html
} 
holders, by placing their works in Noank, pick one of two types of licenses. In the first scheme, reproduction and distribution rights, as well as those that allow the creation of derivative works, are licensed. In the second scheme, this last right is not licensed. The difference between the two schemes leads to a reduction in licensing fees to the assigned work for the owners who choose the latter.

A different kind of blanket license business model was launched in China by Google [4], which shared advertisement revenues with its associates (the four biggest recording labels plus many smaller ones) to offer unlimited free downloads from a catalog of more than one million songs. The objective of this strategy was, from Google's side, to gain market share against Baidu, the biggest search engine in China. From the CPI side, it is clear that the move was aimed to help it increase the pyrrhic revenues obtained from the Chinese music market (estimated as close to US $\$ 90$ million). There are reports that Google was using China as a testing bench to perfect the model and expand it to other countries [31].

\subsubsection{Private initiatives}

Beyond the first private initiatives that attempted to exploit the phenomenon of file sharing through $\mathrm{P}_{2} \mathrm{P}$ networks, such as those of Napster [58] and Grokster [56] that were deemed illegal and thus forced to close operations, the most successful model for the provision of the digital cultural commons has been that of YouTube ${ }^{28}$. Nontheless, by allowing its users to post any content they like, YouTube was exposing itself to the same kind of argument that was used as a beheading tool of both, Napster and Grokster, i.e., its liability to contributory copyright infringement as its application allowed the massive infringement of copyrights by its users. As Driscoll [17] reflected, and later the U.S. District Court for the Southern District of New York stated [61], YouTube should be granted "safe harbor" from the DMCA ${ }^{29}$ sanctions as its behavior was sufficiently different from that of both Napster and Grokster, taking down any infringing content reported by copyright holders. Furthermore, YouTube has established agreements with media giants in exchange of some part of the advertising revenues $[12,51,62,64]$, recently renewing with Warner Music despite a long and particularly bitter process in which the media corporation removed all its contents [10]. A deal has also been signed with the U.S. Government that will allow federal agencies to post contents on Internet through YouTube's service as well as other content providers and social networks [37].

\footnotetext{
${ }^{28}$ According to a study made by comScore, YouTube holds $41 \%$ of the online video market share in the U.S. alone. In second place comes Fox Interactive media with only 3.1\% [13].

${ }^{29}$ The Digital Millenium Copyright Act is the law that oversees the management of copyrights in the digital realm. It states the requirements that, for a particular type of activity, a service or content provider needs to be granted safe harbor protection, a kind of exemption to its users infringement. YouTube falls into the "system storage" safe harbor protection, as it performs "storage at the direction of a user of material that resides on a system or network controlled or operated by the service [or content] provider", lacks "actual knowledge" of the infrigement, and upon proper notice takes measures to remove or block the infringing content. See 17 United States Code (U.S.C.) \$512(c) .
} 
Whether YouTube's business model has been successful is a different story. A report by Credit Suisse [52] originally estimating YouTube's operating losses at $\$ 470$ million, was later revised [53] to include the effect of traffic peering, reducing YouTube's traffic bill from $\$ 360$ million to $\$ 300$ million. RampRate has challenged these figures, estimating operating losses of $\$ 174$ million, by increasing the amount of traffic peered by YouTube, while adding cheaper non-peered traffic due to direct deals with Tier 1 providers and better wholesale rates due to Google's bulk purchasing power [47]. A more recent analysis carried out by Citigroup's analyst Mark Mahaney has upped YouTube's revenue estimation for 2011 to about $\$ 1.1$ billion of which Google will keep $\$ 700$ million. The high variability in these figures comes from YouTube's secrecy, as any word would mean a larger bill in revenue sharing with its media partners.

Independently of YouTube's financial success, it has become what Gehl [32] has defined as a Wunderkammer or "closet of wonders", a digital shelf "waiting either to overwhelm a visitor or to be utilized by savvy new entrepreneurs". This shelf is filled with what its users deem should be saved for posterity, a place where popularity have a different meaning of the concept created by mainstrearm media. But YouTube goes beyond being a place of democratic storage, it is also a showcase for the massive exhibition of these digital objects in such a way that, without directly selling its product to the same people that keeps it alive, a penny can be made on this heavy tailed repositor $y^{30}$.

\section{Internet access as a commons}

\subsection{Commons}

By speaking of "commons" we refer to the ability of a group of people to access a resource without someone from that group having the right or power to exclude anyone else from using it [34]. In regard to whether the commons itself takes place in an open access regime -without regulation- or in a limited access regime -regulated- there is discussion generated from the argument raised by the biologist Garret Hardin's warning of the unsustainability of common resources, "open to everyone", that he called "the tragedy of the commons" [33]. Hardin's commons portray a resource that anybody can access without any restriction to its use. His thesis, has been rebutted by many people who explain that the metaphor used in the model confuses the commons resource with the open access (res nullius) without restrictions ${ }^{31}$.

\footnotetext{
${ }^{30}$ YouTube's success has sprouted many competitors like Vimeo, Hulu and Vevo, the first one applying the democratic aspect of YouTube's storage while generating revenue through ads as well as from power uploaders fees, and the last two allowing content only from the media giants while getting their revenue from paying customers who want to access premium content.

${ }^{31}$ Bollier argues that the pessimistic attitude regarding the sustainability of the commons is maintained in part "because the commons is frequently confused with an open-access regime, a free-for-all in which a resource is essentially open to everyone without restriction." [8] According to Capel [11], communal property has been misinterpreted many times and treated like a free access resource without regulation. Bruce [9] explains that the commons, in the English common law, implies a regulation in the form of access to the common resource.
} 
Regulations have not been limited to defining who was allowed to access the "commons" (it was restricted to commoners to whom the lord gave a use right). The English commons limited the number of animals that villagers could feed in the summer, as they could not exceed the number that could be fed in the winter [15]. The capacity of the land was used to fix a constraint on the use of the commons.

Ellickson [18] considers that it is necessary to differentiate between an open access resource, which everybody can use, and common property, where the resource use is limited to the community. Under a pure or ideal state of open access, each person is authorized to take out resource units, but no person or group of persons have exclusive rights to manage or sell assets. By contrast, the members under a regime of communal property, not only can enter and remove units of the resource, but they also have rights to manage the resource and exclude those who are not members of the community.

Finally, Munzer [41] thinks that the cause of the tragedy of the commons lies in the absence of cooperation, not in the restriction of use, as community members may agree in several ways on how the common resource should be managed. This is what Elinor Ostrom $[43,45,44]$ has shown in her research about the sustainability of the commons.

Therefore, in this paper we will be using the term "commons" for a regulated resource that is non-excludable, but it is rivalrous.

\subsection{Internet layers}

Yochai Benkler [6] sees the Internet as a communication system designed under three interconnected layers that together make the Internet a commons: the physical layer refers to both distribution channel as well as the devices to produce and communicate the information. These devices are controlled by the ISPs or by the Internet users. The logical layer includes the data transmission standards and protocols, e.g. the set of protocols of the TCP/IP model that since its inception was designed and used like a commons. And finally a content layer that includes the cultural expressions that can be stocked and distributed throughout the net, e.g. music, films, books.

All these layers can be free or controlled [38]: they are free when they are organized as a commons and everybody can access them under equal conditions, and they are controlled when somebody has the right and the power to exclude anyone

from its use. At the same time one layer can be both free or controlled like, for example, the content layer, in which we have cultural contents protected by copyright rules and cultural contents under public domain or free access.

\subsection{The open wireless networks as a commons}

Several models have been presented on how wireless networks can be seen as a commons. The most recent, but also the most ambitious, is the supercommons theory laid down by Kevin Werbach [65], in which anyone is allowed to transmit "anywhere, anytime, and in any way", moving regulation from the spectrum to the 
devices. This model focuses on the inefficiency of frequency allocation regulations, and how networks that self allocate frequencies of a commons (e.g. WiMAX), are much more efficient. Benkler [5] referred to this physical layer commons as "open wireless networks".

From the point of view of Internet connectivity, an open wireless network can be seen as a network of wireless access points that are, each one, connected to the Internet through their own link, which is contracted by some individual or group, and that are open for use by other individuals. If the network is open to everyone who wants to use its resources, it acts as a public good. On the other hand, if the network is open only to members of a particular community, then it will be a commons.

An open wireless network is susceptible to free riding, because many users might be willing to use the resources available, but not to open their own access points for the use of others. In [16], we can see that open networks are also vulnerable to overgrazing (over exploitation of the resources), stealing (identity or resources thievery), poaching (blocking of some user's traffic to increase one's own), tainting (spreading, unknowingly, viruses and worms to other users' devices) and contamination (malicious reduction of the bandwidth available to other users).

To guarantee the provision of the open network, one might think that a commons, in which users that would like to tap the available resources are required to provide their own Internet connected wireless access point, is a good solution. But even if each access point is password protected and the passwords are shared between the members of the commons, one or more commoners could provide some of these passwords to family or friends, thus ensuring that the commons' provision would be compromised. Solutions to the other problems require the application of security measures on each user's computer, but, to some extent, the vulnerability of the network is always present. Monitoring of both, resources and users, might help the robustness of the network, but this strategy would be no different from the measures stated in the HADOPI.

A more complex variant of this kind of open wireless network is the model of Benkler [6] in which access points will not only be open to traffic from any user as the commoners decide, but also will have capabilities to search neighboring networks, always securing the best route to send traffic. The ISPs under this architecture would provide access to Internet through these wireless access points, and the last mile should be provided by the cooperative action of the Internet local users behaving as a commons. The presence of a commons in the cooperative last mile throughout the proprietary broadband, removes the bottleneck that ISPs set on last miles to control what is sent, to whom and with what level of productivity and interactivity. Again, the network will be only as open as the last mile commoners decide.

\section{Conclusions}

This paper complements our analysis in $[69,1,2]$. In [69] we have presented an introduction to the interplay between legislation and information technology that 
accompanied the developments of the Internet along with the possibilities it opened for free access to copyrighted music and films. We have have studied, in particular, the various actors involved, their interests and the interactions between the various actors. Economic modeling of these conflicts along with that of alternative approaches for collaboration between actors was presented in [2]. In this paper we presented the historical and ideological contexts of the conflicts that are due to the very wide access to culture and knowledge that the Internet technology opens. We highlighted the central role that the access to the Internet plays in what many countries understand as basic human rights. We further summarized the economic identification of the Internet with the concept of public goods, and of the access to it as commons. Finally, in [1] we have studied the impact that the so called "sampling effect" and the CPI's legal prosecution strategy carried out against random file sharers had have on sales, pointing out that only attractive pricing schemes can tip file sharers' behavior into that of regular customers.

Our main conclusion is that there is quite a consensus that the Internet is a tool for the exercise of the freedom of speech and that the access to it is an elementary right. This access, however, will have limitations when it comes into conflict with other rights. At present there seems to be an agreement on what such rights are. Yet, there is a strong debate on the way to guarantee those rights, with the confrontational approach on the one hand, aiming at banning physical access to copyrighted content on the Internet, and on the other hand the approach aiming at taxing such access.

The future Internet will be very much influenced by the legal and economic positions that nations adopt in the abovementioned debate. In particular, with a confrontational approach winning, we may expect a shift from research on $\mathrm{P}_{2} \mathrm{P}$ file sharing, towards research on identifying copyright infringers.

\section{References}

\section{References}

[1] Eitan Altman, Sulan Wong, and Julio Rojas-Mora. $\mathrm{P}_{2} \mathrm{P}$ business and legal models for increasing accessibility to popular culture. In Proceedings of the DIGIBIZ 2009 Conference, London, 2009.

[2] Eitan Altman, Sulan Wong, Julio Rojas-Mora, and Alireza Aram. Cooperative solutions to unauthorized download of copyrighted creations (manuscript), 2009.

[3] Asociación de Internautas. La Asociación de Internautas recurre el canon digital ante la Audiencia Nacional, 2008.

[4] David Barboza. Google offers links to free music downloads in China. The Wall Street Journal, March 2009. 
[5] Yochai Benkler. Some economics of wireless communications. Harvard Journal of Law \& Technology, 16(1):25-83, 2002.

[6] Yochai Benkler. The wealth of networks: how social production transforms markets and freedom. Yale University Press, London, online version avaible under a Creative Commons Noncomercial Sharealike license edition, 2006.

[7] Norberto Bobbio. Estudios de historia de la filosofía: de Hobbes a Gramsci. Debate, Madrid, 1985.

[8] David Bollier. Reclaiming the commons, 2002. http://www . bostonreview. net/BR27.3/bollier.html.

[9] John W. Bruce. Conceptos sobre tenencia de la tierra. Tenure Brief, (1-S):1-8, 2000. Traducción española de Citlali, Cortés Montaño.

[10] Eliot Van Buskirk. Warner's Music Returns to YouTube Following Nine Month Hiatus (UPDATED). WIRED.com, 2009. Reviewed on 07/28/2010. URL: http://www.wired.com/epicenter/2009/09/ warner-music-group-signs-youtube-deal.

[11] Horacio Capel. El drama de los bienes comunes. La necesidad de un programa de investigación. Biblio 3 W, Revista Bibliográfica de Geografía y Ciencias Sociales, VIII(458), 82003.

[12] CBS Corporation and YouTube, Inc. CBS and YouTube Strike Strategic Content and Advertising Partnership, 2006. Reviewed on 07/28/2010. URL: http: //www . youtube.com/press_room_entry?entry=iXG7e1g-BWI.

[13] comScore, Inc. Americans Viewed a Record 16.8 Billion Videos Online in April Driven Largely by Surge in Viewership at YouTube, 2009. Reviewed on 07/28/2010. URL: http://www . comscore.com/Press_Events/Press_ Releases/2009/6/Americans_Viewed_a_Record_16.8_Billion_ Videos_Online_in_April.

[14] Conseil Constitutionnel. Décision Nro. 2009-580 DC du 10 juin (Loi favorisant la diffusion et la protection de la création sur internet), 2009.

[15] Susan Jane Buck Cox. No tragedy on the commons. Environmental Ethics, 7, 1985.

[16] Jan Damsgaard, Mihir A. Parikh, and Bharat Rao. Wireless commons perils in the commons good: individuals acting in their own self interest over time can destroy a wireless commons. Comunications of the ACM, 49(2):105-109, 2006.

[17] Michael Driscoll. Will YouTube Sail into the DMCA's Safe Harbor or Sink for Internet Piracy? The John Marshall Review of Intellectual Property Law, 6:550-569, 2007. 
[18] Robert C. Ellickson. Property in land. The Yale Law Journal, 102:1315-1400, 1993.

[19] European Commission. Stakeholder consultation on copyright levies in a converging world, June 2006.

[20] European Commission. Background document: "Fair compensation" for acts of private copying, February 2008.

[21] European Commission. Commission position on Amendment 138 adopted by the European Parliament in plenary vote on 24 September. Europa Press releases RAPID, MEMO/o8/681, 2008.

[22] European Parliament. European Parliament recommendation of 26 March 2009 to the Council on strengthening security and fundamental freedoms on the Internet (P6 TA(2009)0194), March 2009.

[23] European Parliament. Telecom markets: still no overall agreement with council presidency. Press release, April 2009.

[24] European Parliament. European Parliament resolution of 10 March 2010 on the transparency and state of play of the ACTA negotiations ( $\mathrm{P}_{7}$ TA(2010)0058), 2010.

[25] European Parliament and Council of the European Union. Directive 2001/29/ of 22 May 2001 on the harmonisation of certain aspects of copyright and related rights in the information society. Official Journal of the European Communities L167/10, 2001.

[26] European Parliament and Council of the European Union. Directive 2002/22/EC of the European Parliament and of the Council of 7 March 2002 on universal service and users' rights relating to electronic communications networks and services (Universal Service Directive). Official Journal L 108 , 24/04/2002 P. 0051 - 0077, March 2002.

[27] European Parliament and Council of the European Union. Legislative resolution of 24 September 2008 on the proposal for a directive of the European Parliament and of the Council amending Directive 2002/21/EC on a common regulatory framework for electronic communications networks and services, Directive 2002/19/EC on access to, and interconnection of, electronic communications networks and associated facilities, and Directive 2002/20/EC on the authorisation of electronic communications networks and services, 2008.

[28] European Parliament and Council of the European Union. Directive 2009/136/EC of the European Parliament and of the Council of 25 November 2009 amending Directive 2002/22/EC on universal service and users' rights relating to electronic communications networks and services, Directive 2002/58/EC 
concerning the processing of personal data and the protection of privacy in the electronic communications sector and Regulation (EC) No 2006/2004 on cooperation between national authorities responsible for the enforcement of consumer protection laws. Official Journal of the European Union L337, December 2009.

[29] European Union. Charter of Fundamental Rights of The European Union (2000/C 364/o1). Official Journal of the European Communities $\mathrm{C}_{3} 64 / 1$, Volume 43,18 December, 2000.

[30] William Fisher. Promises to Keep: Techonology, Law, and the Future of Entertainment. Stanford University Press, 2004.

[31] Owen Fletcher. Google may take music downloads beyond china. PC World, June 2009.

[32] Robert Gehl. YouTube as archive: Who will curate this digital Wunderkammer? International Journal of Cultural Studies, 12(1):43-60, 2009.

[33] Garrett Hardin. The tragedy of the commons. Science, 162(3859):1243-1248, December 1968.

[34] Charlotte Hess and Elinor Ostrom. Introduction: An overview of the knowledge commons. In Charlotte Hess and Elinor Ostrom, editors, Understanding Knowledge as a Commons, chapter 1, pages 4-26. MIT Press, Cambridge, Massachusetts, 2007.

[35] George Jellinek. La declaración de los derechos del hombre y del ciudadano. Universidad Nacional Autónoma, México, 2000.

[36] Martin Kuhr. Media windows in flux: Challenges for audiovisual media chronology. Iris Plus: Legal Observations of the European Audiovisual Observatory, 4:2-8, 2008.

[37] Frederic Lardinois. Making it Official: Government Agencies Sign Agreements with YouTube, Flickr, Vimeo, and Blip. ReadWriteWeb, 2009. Reviewed on 07/28/2010. URL: http://www.readwriteweb.com/archives/ government_agencies_sign_agreement_with_web20_services.php.

[38] Lawrence Lessig. The architecture of innovation. Duke Law Journal, 51:1783$1788,2002$.

[39] Ministre de la Justice et des Liberteés. Projet de Loi relatif á la protection pénale de la propiété littéraire et artistique sur internet (PROCÉDURE ACCÉLÉRÉE ENGAGÉE), Juin 2009. Texte Nro. 498 (2008-2009).

[40] Ministry of Transport and Communications of Finland. Decree on the minimun rate of a funcional Internet access as a universal service (732/2009), 2009. 
[41] Stephen R. Munzer. The commons and the anticommons in the law and theory of property. In Martin P. Golding and William A. Edmundson, editors, The Blackwell Guide to the Philosophy of Law and Legal Theory, pages 148-162. Blackwell Publishing, Oxford, 2005.

[42] Mancur Olson. The Logic of Collective Action: Public Goods and Theory of Groups. Harvard University Press, Cambridge, 1965. 2nd edition, 1971.

[43] Elinor Ostrom. Governing the commons: the evolution of institutions for collective action. Cambridge University Press, Cambridge, 1990.

[44] Elinor Ostrom, Joanna Burger, Christopher B. Field, Richard B. Norgaard, and David Policansky. Revisiting the Commons: Local Lessons, Global Challenges. Science, 284(5412):278-282, 1999.

[45] Elinor Ostrom, Thomas Dietz, Nives Dolsak, Paul C. Stern, Susan Stonich, and Elke U. Weber. The drama of the commons. The National Academies Press, 2002.

[46] Antonio Enrique Pérez Luño. Derechos humanos, Estado de derecho y Constitución. Tecnos, Madrid, 9th edition, 1984.

[47] RampRate. YouTube Google's Phantom Loss Leader, 2009. Reviewed on 07/28/2010. URL: http://www.ramprate.com/2009/06/ youtube-googles-phantom-loss-leader/.

[48] Reino de España. Ley 23/2006, de 7 de julio, por la que se modifica el texto refundido de la Ley de Propiedad Intelectual, aprobado por el Real Decreto Legislativo 1/1996, de 12 de abril. Boletín Oficial del Estado, No 162, 8 de Julio, 2006.

[49] Reino de España. Orden PRE/1743/20o8, de 18 de junio, por la que se establece la relación de equipos, aparatos y soportes materiales sujetos al pago de la compensación equitativa por copia privada, las cantidades aplicables a cada uno de ellos y la distribución entre las diferentes modalidades. Boletín Oficial del Estado, Nro. 148 de 19/06/2008, 2008.

[50] Paul A. Samuelson. The pure theory of public expenditure. The Review of Economics and Statistics, 36(4):387-389, 1954.

[51] Sony BMG Music Entertainment and YouTube, Inc. Sony BMG Music Entertainment Signs Content License Agreement With YouTube, 2006. Reviewed on 07/28/2010. URL: http://www.youtube.com/press_room_ entry?entry $=2 \mathrm{cwCau} 7 \mathrm{cKsA}$.

[52] Todd Spangler. YouTube May Lose $\$ 470$ Million In 2009: Analysts. Multichannel News, 2009. Reviewed on 07/28/2010. URL: http://www. multichannel . com/article/191223-YouTube_May_ Lose_470_Million_In_2009_Analysts.php. 
[53] Todd Spangler. YouTube's Bandwidth Bill Estimated At \$300M For 2009. Multichannel News, 2009. Reviewed on 07/28/2010. URL: http://www. multichannel.com/article/339947-YouTube_s_ Bandwidth_Bill_Estimated_At_300M_For_2009.php.

[54] Supreme Court of the United States of America. Janet Reno, Attorney General of the United States, et al., v. American Civil Liberties Union et al., 521 U.S. 844, 81997.

[55] Supreme Court of the United States of America. John Ascroft, Attorney General v. American Civil Liberties Union, 535 U.S. 564, May 2002.

[56] Supreme Court of the United States of America. Metro Goldwyn Mayer Studios et al. v. Grokster, Ltd., et al., 545 U.S. 913, 2005.

[57] Todos contra el canon. Derecho de petición presentado al Presidente del Congreso de los Diputados, Mayo 2009.

[58] United States Court of Appeals for the Ninth Circuit. A\&M Records, Inc., et al., v. Napster, Inc., 239 F.3d 1004, 2001.

[59] United States Court of Appeals for the Third Circuit. American Civil Liberties Union et al., v. Janet Reno, Attorney General of the United States, 217 F.3d 162, June 2000 .

[6o] United States District Court for the Eastern District of Pennsylvania. American Civil Liberties Union et al. v Janet Reno, Attorney General of the United States, No. 96-963, 1996.

[61] United States District Court for the Southern District of New York. VIACOM International Inc. et al., v. YouTube, Inc. et al., o7 Civ. 2103 (LLS), June 2010.

[62] Universal Music Group and YouTube, Inc. Universal Music Group and YouTube Forge Strategic Partnership, 2006. Reviewed on 07/28/2010. URL: http: $/ /$ new . umusic . com/News . aspx?NewsId $=426$.

[63] Fred von Lohmann. A better way forward: Voluntary collective licensing of music file sharing. Technical report, Electronic Frontier Foundation, 2008.

[64] Warner Music Group Corp. and YouTube, Inc. Warner Music Group and YouTube Announce Landmark Video Distribution and Revenue Partnership, 2006. Reviewed on 07/28/2010. URL: http://investors .wmg.com/ phoenix .zhtml? c=182480\&p=irol-newsArticle\&ID=906153.

[65] Kevin Werbach. Supercommons: Toward a unified theory of wireless communication. Texas Law Review, 82:863-963, 2004.

[66] WIPO. Berne Convention for the Protection of Literary and Artistic Works, 1886. As revised. 
[67] WIPO. Copyright Treaty, 1996.

[68] WIPO. Performances and Phonograms Treaty (adopted in Geneva on December 20, 1996), 1996.

[69] Sulan Wong, Eitan Altman, and Mouhamad Ibrahim. P2P Networks: The interplay between legislation and information technology. Technical Report 6889, Institute National de Recherche en Informatique et en Automatique (INRIA), 2009.

[70] WTO. Trade Related Aspects of Intellectual Property Rights (TRIPS), 1995. 
Centre de recherche INRIA Sophia Antipolis - Méditerranée 2004, route des Lucioles - BP 93 - 06902 Sophia Antipolis Cedex (France)

Centre de recherche INRIA Bordeaux - Sud Ouest : Domaine Universitaire - 351, cours de la Libération - 33405 Talence Cedex Centre de recherche INRIA Grenoble - Rhône-Alpes : 655, avenue de l'Europe - 38334 Montbonnot Saint-Ismier Centre de recherche INRIA Lille - Nord Europe : Parc Scientifique de la Haute Borne - 40, avenue Halley - 59650 Villeneuve d'Ascq Centre de recherche INRIA Nancy - Grand Est : LORIA, Technopôle de Nancy-Brabois - Campus scientifique 615, rue du Jardin Botanique - BP 101 - 54602 Villers-lès-Nancy Cedex

Centre de recherche INRIA Paris - Rocquencourt : Domaine de Voluceau - Rocquencourt - BP 105 - 78153 Le Chesnay Cedex

Centre de recherche INRIA Rennes - Bretagne Atlantique : IRISA, Campus universitaire de Beaulieu - 35042 Rennes Cedex Centre de recherche INRIA Saclay - Île-de-France : Parc Orsay Université - ZAC des Vignes : 4, rue Jacques Monod - 91893 Orsay Cedex 